Prepared in cooperation with the National Park Service, Whiskeytown National Recreation Area and the Burned Area Response Program

Concentrations of Mercury and other Metals in Black Bass (Micropterus spp.) from Whiskeytown Lake, Shasta County, California, 2005

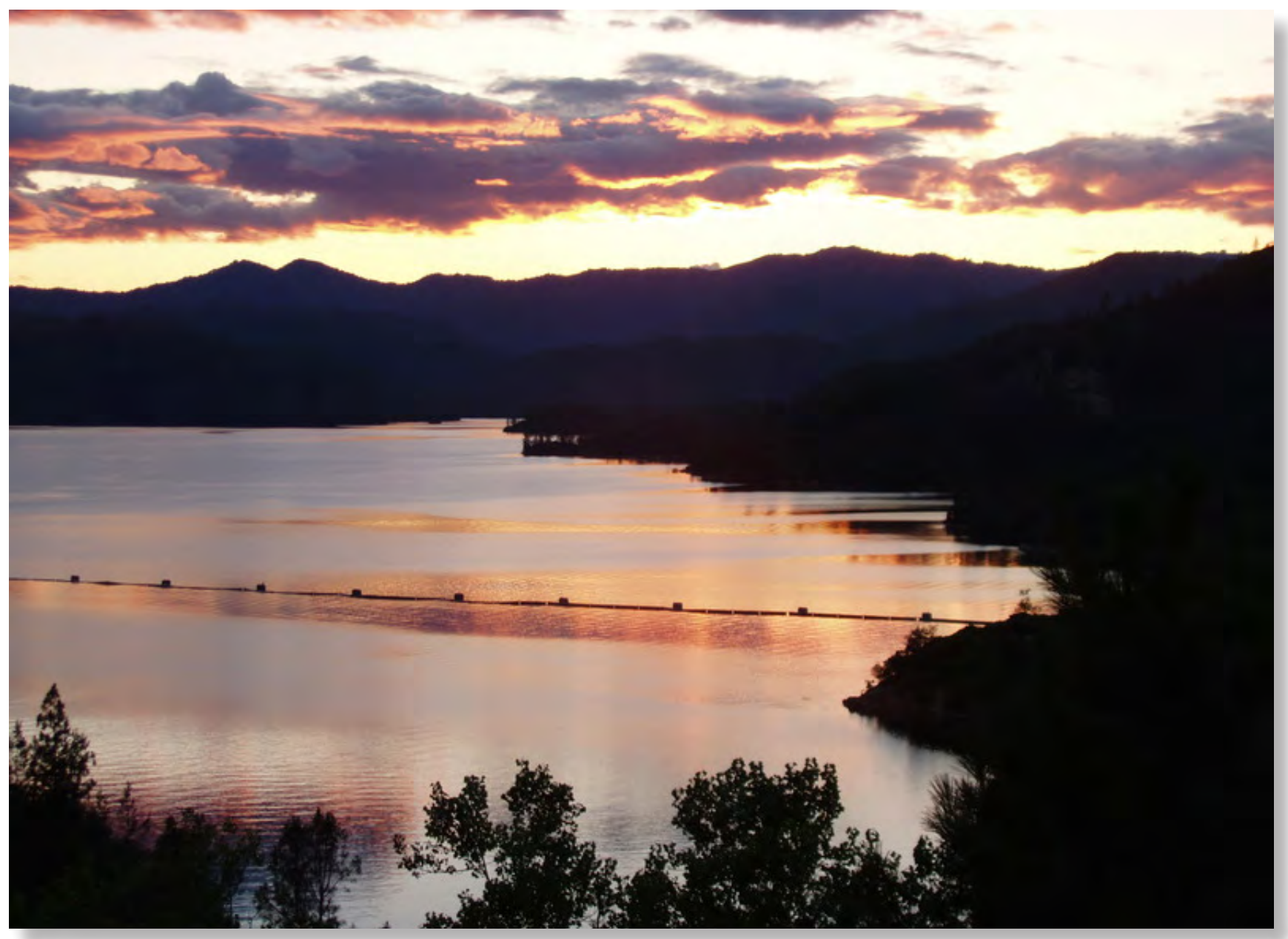

Open File Report 2011-1297 



\section{Concentrations of Mercury and other Metals in Black Bass (Micropterus spp.) from Whiskeytown Lake, Shasta County, California, 2005}

By Jason T. May, Roger L. Hothem, Marissa L. Bauer, and Larry R. Brown

Prepared in cooperation with the National Park Service, Whiskeytown National

Recreation Area and the Burned Area Response Program

Open-File Report 2011-1297 


\section{U.S. Department of the Interior \\ KEN SALAZAR, Secretary \\ U.S. Geological Survey \\ Marcia K. McNutt, Director}

U.S. Geological Survey, Reston, Virginia: 2012

For more information on the USGS - the Federal source for science about the Earth, its natural and living resources, natural hazards, and the environment, visit http://www.usgs.gov or call 1-888-ASK-USGS.

For an overview of USGS information products, including maps, imagery, and publications, visit http://www.usgs.gov/pubprod

To order this and other USGS information products, visit http://store.usgs.gov

Any use of trade, product, or firm names is for descriptive purposes only and does not imply endorsement by the U.S. Government.

Although this report is in the public domain, permission must be secured from the individual copyright owners to

reproduce any copyrighted materials contained within this report.

Suggested citation:

May, J.T., Hothem, R.L., Bauer, M.L., and Brown, L.R., 2012, Concentrations of mercury and other metals in black bass (Micropterus spp.) from Whiskeytown Lake, Shasta County, California, 2005: U.S. Geological Survey, Open-File Report 2011-1297, 16 p. 


\section{Contents}

Abstract
Introduction.
Purpose and Scope
Field Methods and Sample Preservation Techniques
Laboratory Methods of Chemical Analysis
Quality Assurance and Quality Control
Results and Discussion
Acknowledgements
References.

\section{Figures}

1. Map showing fish sampling locations within Whiskeytown Lake, Shasta County, California

2. Graph showing mercury concentration for all bass (Micropterus spp.) samples collected from Whiskeytown Lake, California, 2005, in relation to total length

3. Correlation plot of mercury concentration in fillet samples in relation to whole-body samples for for all bass (Micropterus spp.) samples collected from Whiskeytown Lake, California, 2005

\section{Tables}

1. Sites within Whiskeytown Lake, California, sampled during 2005

2. Total mercury concentrations in fillet and whole-body samples of largemouth bass (Micropterus salmoides) and spotted bass (M. punctulatus) collected from Whiskeytown Lake, California, June 7-9, 2005.

3. Concentrations of selected metals and sulfur in whole-body samples of largemouth bass (Micropterus salmoides) and spotted bass (Micropterus punctulatus) collected from Whiskeytown Lake, California, June 2005 


\section{Conversion Factors, Horizontal Datum, Acronym and Abbreviations, and Chemical Elements}

\section{Conversion Factors}

Si to Inch/Pound

\begin{tabular}{lcl}
\hline \multicolumn{1}{c}{ Multiply } & By & \multicolumn{1}{c}{ To obtain } \\
\hline \multicolumn{3}{c}{ Length } \\
\hline millimeter $(\mathrm{mm})$ & 0.03937 & inch (in) \\
\hline microgram $(\mu \mathrm{g})$ & Mass \\
milligram $(\mathrm{mg})$ & 0.000000035 & ounce, avoirdupois $(\mathrm{oz})$ \\
gram $(\mathrm{g})$ & 0.000035 & ounce, avoirdupois $(\mathrm{oz})$ \\
kilogram $(\mathrm{kg})$ & & ounce, avoirdupois $(\mathrm{oz})$ \\
& 2.205 & pound avoirdupois $(\mathrm{lb})$ \\
\hline
\end{tabular}

Temperature in degrees Celsius $\left({ }^{\circ} \mathrm{C}\right)$ may be converted to degrees Fahrenheit $\left({ }^{\circ} \mathrm{F}\right)$ as follows:

${ }^{\circ} \mathrm{F}=\left(1.8 \mathrm{x}^{\circ} \mathrm{C}\right)+32$

Horizontal coordinate information is referenced to the "North American Datum of 1983 (NAD $83)^{\prime \prime}$

Concentrations of chemical constituents in water are given either in milligrams per liter (mg/L) or micrograms per liter $(\mu \mathrm{g} / \mathrm{L})$.

\section{Acronyms, Abbreviations, and Chemical Notation}

(additional information given in parentheses)

$\begin{array}{ll}\text { CRV } & \text { certified reference value } \\ \text { CVAAS } & \text { cold vapor atomic-absorption spectroscopy } \\ \text { CVAFS } & \text { cold vapor atomic-fluorescence spectrometry } \\ \text { dw } & \text { dry weight } \\ \text { ICP-MS } & \text { coupled plasma-mass spectroscopy } \\ \text { ICP-OES } & \text { inductively coupled plasma-optical emission spectroscopy } \\ \text { LOD } & \text { limit of detection } \\ \text { MDL } & \text { method detection limit } \\ \text { MOhm } & \text { megaohm } \\ \text { NPS } & \text { National Parks Service } \\ \text { NRA } & \text { National Recreation Area } \\ \text { NRCC } & \text { National Research Council of Canada } \\ \text { OEHHA } & \text { Office of Environmental Health Hazard Assessment } \\ \text { OA } & \text { quality assurance } \\ \text { OC } & \text { quality control }\end{array}$




$\begin{array}{ll}\text { RPD } & \text { relative percent difference } \\ \text { SRM } & \text { standard reference material } \\ \text { SV } & \text { screening value } \\ \text { TERL } & \text { Trace Element Research Laboratory (College Station, Texas) } \\ \text { USEPA } & \text { U.S. Environmental Protection Agency } \\ \text { USGS } & \text { U.S. Geological Survey } \\ \text { WHIS } & \text { Whiskeytown National Recreation Area } \\ \text { v/v } & \text { The formula for volume percent (v/v) is: [Volume of solute (mL)/ } \\ & \text { Volume of solution (mL)] x 100 } \\ \text { WW } & \text { wet weight } \\ \text { HgT } & \text { total mercury } \\ \text { Hg }{ }^{2+} & \text { divalent mercury } \\ \text { ppm } & \text { part per million ( } \mu \mathrm{g} / \mathrm{g} \text { ) } \\ \mathrm{spp} . & \text { species (plural) } \\ \text { WHIS } & \text { Whiskeytown National Recreation Area }\end{array}$

\section{Chemical Elements}

Al

As

$\mathrm{Ag}$

B

$\mathrm{Ba}$

$\mathrm{Be}$

$\mathrm{Ca}$

$\mathrm{Cd}$

Co

$\mathrm{Cr}$

$\mathrm{Cu}$

$\mathrm{Fe}$

$\mathrm{Hg}$

K

$\mathrm{Mg}$

$\mathrm{Mn}$

Mo

$\mathrm{Na}$

$\mathrm{Ni}$

$P$

$\mathrm{Pb}$

$S$

Se aluminum

arsenic

silver

boron

barium

beryllium

calcium

cadmium

cobalt

chromium

copper

iron

mercury

potassium

magnesium

manganese

molybdenum

sodium

nickel

phosphorus

lead

sulfur

selenium 


$\begin{array}{ll}\mathrm{Sr} & \text { strontium } \\ \mathrm{Ti} & \text { titanium } \\ \mathrm{V} & \text { vanadium } \\ \mathrm{Zn} & \text { zinc }\end{array}$

\section{Chemical Compounds, Isotopes, and other Chemical Notation}

\begin{tabular}{|c|c|}
\hline $\mathrm{CH}_{3}$ & methyl radical \\
\hline $\mathrm{CH}_{4}$ & methane \\
\hline $\mathrm{CH}_{2} \mathrm{Cl}_{2}$ & methylene chloride \\
\hline $\mathrm{CuSO}_{4}$ & copper sulfate \\
\hline $\mathrm{Fe}(\mathrm{II})$ & ferrous (divalent) iron \\
\hline $\mathrm{Fe}(\mathrm{III})$ & ferric (trivalent) iron \\
\hline $\mathrm{HCl}$ & hydrochloric acid \\
\hline HF & hydrofluoric acid \\
\hline $\mathrm{HNO}_{3}$ & nitric acid \\
\hline $\mathrm{HgO}$ & elemental mercury \\
\hline $\mathrm{Hg}^{+}$ & mercurous ion \\
\hline $\mathrm{Hg}^{2+}$ & mercuric ion \\
\hline $\mathrm{Hg}(I I)$ & divalent mercury \\
\hline $\mathrm{HgCl}_{2}$ & mercuric chloride \\
\hline $\mathrm{HgT}$ & total mercury \\
\hline${ }_{203} \mathrm{Hg}(\mathrm{II})$ & mercury-203 radiotracer divalent inorganic mercury \\
\hline $\mathrm{KBr}$ & potassium bromide \\
\hline $\mathrm{MeHg}$ & methylmercury (monomethylmercury) \\
\hline $\mathrm{N}_{2}$ & nitrogen gas \\
\hline $\mathrm{NaBEt}_{4}$ & sodium tetra-ethyl borate \\
\hline $\mathrm{O}_{2}$ & oxygen gas \\
\hline $\mathrm{SiO}_{2}$ & silicon dioxide, or silica \\
\hline $\mathrm{SnCl}$ & stannous chloride \\
\hline
\end{tabular}




\title{
Concentrations of Mercury and other Metals in Black Bass (Micropterus spp.) from Whiskeytown Lake, Shasta County, California, 2005
}

\author{
By Jason T. May', Roger L. Hothem², Marissa L. Bauer', and Larry R. Brown ${ }^{1}$
}

\begin{abstract}
This report presents the results of a reconnaissance study conducted by the U.S. Geological Survey (USGS) to determine mercury $(\mathrm{Hg})$ and other selected metal concentrations in Black bass (Micropterus spp.) from Whiskeytown Lake, Shasta County, California. Total mercury concentrations were determined by cold-vapor atomic absorption spectroscopy (CVAAS) in fillets and whole bodies of each sampled fish. Selected metals scans were performed on whole bodies (less the fillets) by inductively coupled plasma-mass spectroscopy (ICP-MS) and inductively coupled plasma-optical emission spectroscopy (ICP-OES). Mercury concentrations in fillet samples ranged from 0.06 to 0.52 micrograms per gram $(\mu \mathrm{g} / \mathrm{g})$ wet weight (ww). Total mercury (HgT) in the same fish whole-body samples ranged from 0.04 to $0.37(\mu \mathrm{g} / \mathrm{g}$, ww). Mercury concentrations in 17 percent of "legal catch size" ( $\geq 305$ millimeters in length) were above the U.S. Environmental Protection Agency water-quality criterion for the protection of human health of $0.30 \mu \mathrm{g} / \mathrm{g}$ (ww). These data will serve as a baseline for future monitoring efforts within Whiskeytown Lake.
\end{abstract}

\section{Introduction}

Historic gold mining and naturally occurring mercury from geothermal sources has left many areas of California subject to mercury contamination. (California Department of Conservation, 2000; Alpers and others, 2005). The KlamathTrinity Mountains Region, specifically Trinity Lake and the upstream watershed, have previously documented elevated levels of mercury in resident sport fish (May and others, 2005). The highest density historical mine sites within the Clear Creek Watershed occur in the upper Clear Creek area, and are likely sources of contamination to the local environment and Whiskeytown Lake (fig. 1; Moore and Hughes, 2003). Run-off from abandoned mine lands has resulted in elevated levels of metals in the stream sediments (Moore and Hughes, 2003). Pristine water quality was identified by the Whiskeytown National Recreation Area (WHIS) and the National Parks Service (NPS) as WHIS's Government Performance Results Act Goal Ia4 in their General Management Plan (National Parks Service, 1999). Whiskeytown Lake also serves as the domestic water supply for several nearby cities including Redding and Anderson. Additionally, the lake stores water for the Central Valley Project and functions as a major recreation area in Northern California, providing recreation for 700,000 visitors annually. Sport fishing is a popular recreational activity at Whiskeytown Lake and its tributaries. The lake supports recreational fishing for several species including two black bass species, largemouth bass (Micropterus salmoides) and spotted bass (M. punctulatus), which were collected as part of this reconnaissance effort. These lake fish samples are part of an ongoing effort that was begun in 2002 to characterize and monitor mercury and other metals 'hot spots' in the Upper Clear Creek watershed and WHIS.

During 2005, the U.S. Geological Survey (USGS) conducted a reconnaissance investigation in cooperation with the WHIS to assess mercury contamination associated with historical mining in the Clear Creek watershed. During this study, the USGS collected 63 black bass (44 largemouth bass and 19 spotted bass) from three locations within Whiskeytown Lake: Clear Creek, Brandy Creek, and Whiskey Creek arms (fig. 1; tables 1 and 2). Mercury levels were determined in boneless/ skinless fillet tissue of each fish and the remaining whole-body sample of the same fish. Additional trace-metal analyses were also done on the remaining whole body. 


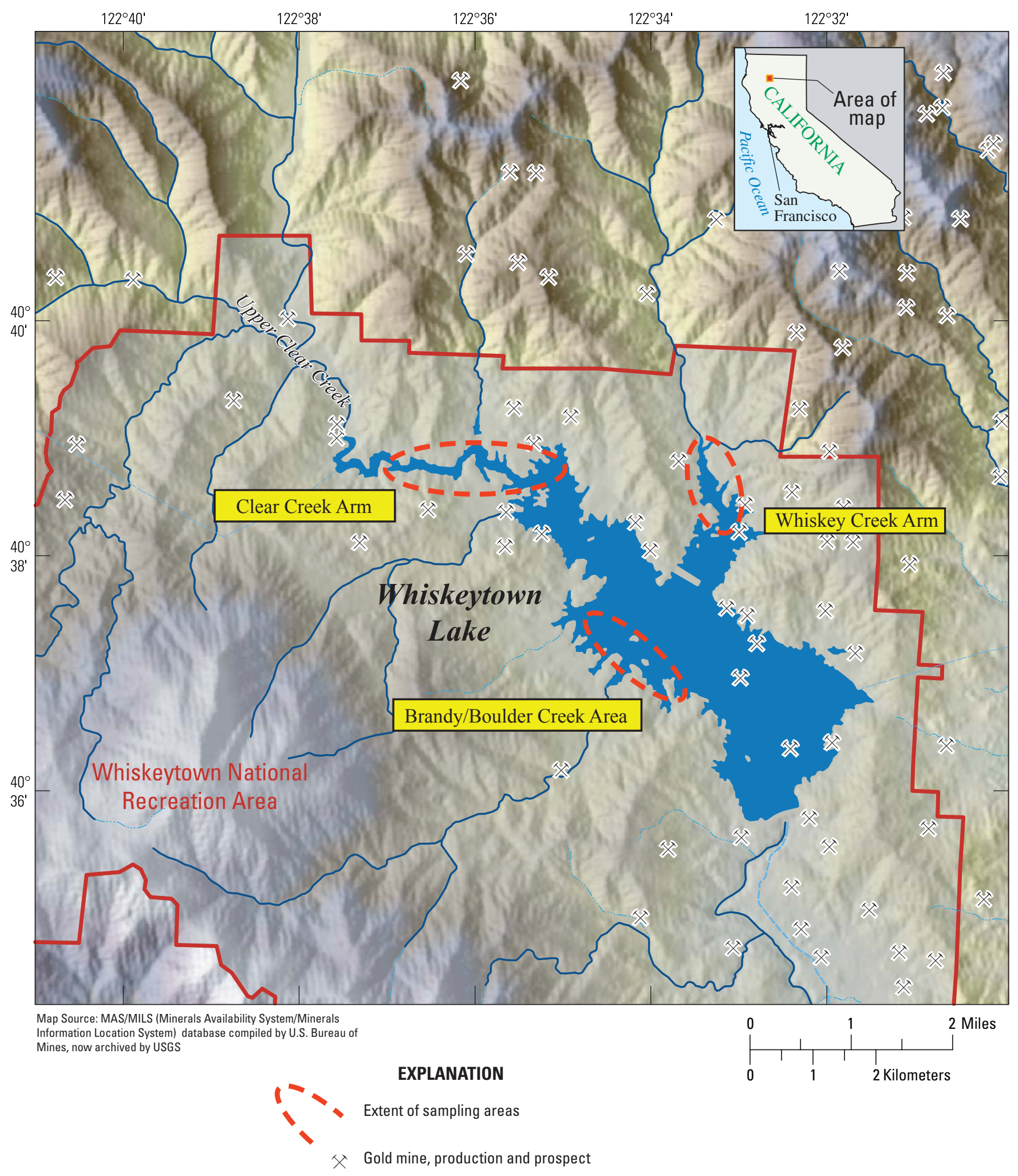

Figure 1. Fish sampling locations within Whiskeytown Lake, Shasta County, California. 
Table 1. Sites within Whiskeytown Lake, California, sampled during 2005.

[USGS, U.S. Geological Survey; ${ }^{\circ}$, degree; ', minutes; N, north; W, west]

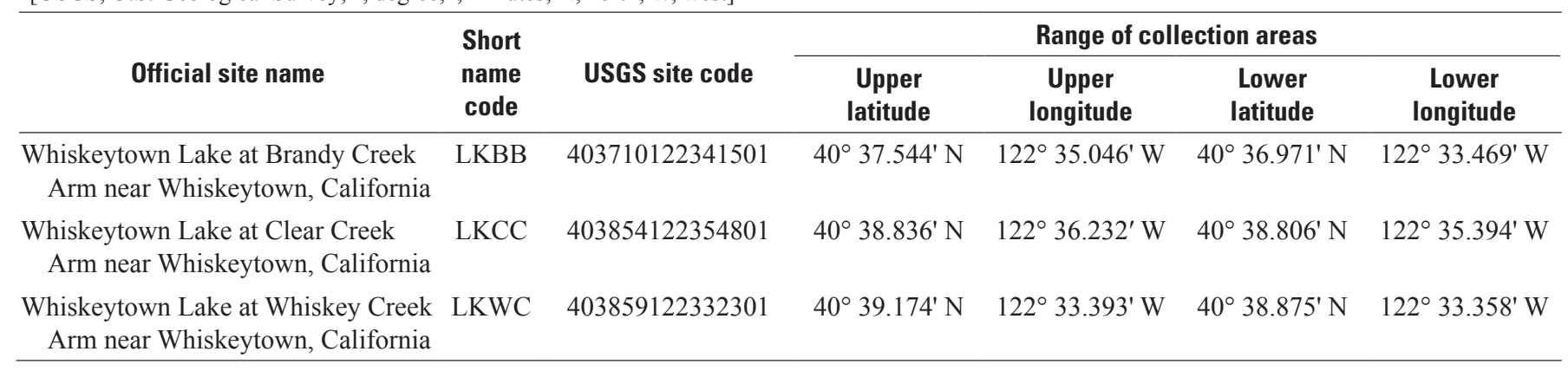

Table 2. Total mercury concentrations in fillet and whole-body samples of largemouth bass (Micropterus salmoides) and spotted bass (M. punctulatus) collected from Whiskeytown Lake, California, June 7-9, 2005.

[LKBB, Brandy/Boulder Creek area; LKCC, Clear Creek arm; LKWC, Whiskey Creek arm; LMBA, largemouth bass; SPBA, spotted bass; HgT, total mercury; g, gram; $\mu \mathrm{g}$; microgram; mm, millimeter; wt., weight]

\begin{tabular}{|c|c|c|c|c|c|c|c|c|c|c|}
\hline Site & Species & $\begin{array}{c}\text { Total } \\
\text { length } \\
(\mathrm{mm})\end{array}$ & Fillet code & $\begin{array}{c}\text { Fillet } \\
\text { sample } \\
\text { mass } \\
\text { (g) }\end{array}$ & $\begin{array}{c}\text { Fillet HgT } \\
\text { ( } \mu \mathrm{g} / \mathrm{g}, \\
\text { wet wt.) }\end{array}$ & $\begin{array}{c}\text { Fillet } \\
\text { moisture } \\
\text { (percent) }\end{array}$ & $\begin{array}{l}\text { Whole-body } \\
\text { code }\end{array}$ & $\begin{array}{l}\text { Whole } \\
\text { body } \\
\text { sample } \\
\text { mass (g) }\end{array}$ & $\begin{array}{c}\text { Whole } \\
\text { body HgT } \\
\text { ( } \mu \mathrm{g} / \mathrm{g}, \\
\text { wet wt.) }\end{array}$ & $\begin{array}{c}\text { Whole } \\
\text { body } \\
\text { moisture } \\
\text { (percent) }\end{array}$ \\
\hline LKBB & LMBA & 360 & LKBB-060705-001F & 63.7 & 0.119 & 81.8 & LKBB-060705-001W & 644.1 & 0.088 & 76.7 \\
\hline LKBB & LMBA & 382 & LKBB-060705-002F & 76.7 & 0.157 & 82.6 & LKBB-060705-002W & 684.0 & 0.108 & 77.6 \\
\hline LKBB & LMBA & 403 & LKBB-060705-003F & 114.5 & 0.343 & 80.4 & LKBB-060705-003W & 878.6 & 0.219 & 73.3 \\
\hline LKBB & LMBA & 325 & LKBB-060705-007F & 62.3 & 0.214 & 81.4 & LKBB-060705-007W & 405.4 & 0.146 & 76.6 \\
\hline LKBB & LMBA & 330 & LKBB-060705-008F & 53.5 & 0.198 & 81.3 & LKBB-060705-008W & 432.1 & 0.123 & 75.4 \\
\hline LKBB & LMBA & 315 & LKBB-060705-009F & 43.7 & 0.169 & 81.7 & LKBB-060705-009W & 279.6 & 0.132 & 77.1 \\
\hline LKBB & LMBA & 318 & LKBB-060705-011F & 34.8 & 0.084 & 81.7 & LKBB-060705-011W & 390.2 & 0.052 & 77.4 \\
\hline LKBB & SPBA & 385 & LKBB-060705-005F & 76.1 & 0.233 & 79.7 & LKBB-060705-005W & 708.6 & 0.167 & 73.1 \\
\hline LKBB & SPBA & 327 & LKBB-060705-012F & 28.5 & 0.209 & 82 & LKBB-060705-012W & 334.1 & 0.173 & 76.3 \\
\hline LKBB & SPBA & 293 & LKBB-060705-013F & 15.7 & 0.091 & 81.1 & LKBB-060705-013W & 261.2 & 0.069 & 75.5 \\
\hline LKBB & SPBA & 311 & LKBB-060705-014F & 28.1 & 0.267 & 80.9 & LKBB-060705-014W & 337.7 & 0.192 & 76.5 \\
\hline LKBB & SPBA & 249 & LKBB-060705-017F & 23.7 & 0.104 & 79.5 & LKBB-060705-017W & 152.2 & 0.073 & 75.6 \\
\hline LKBB & SPBA & 238 & LKBB-060705-018F & 18.6 & 0.118 & 79.8 & LKBB-060705-018W & 148.4 & 0.085 & 74.3 \\
\hline LKBB & SPBA & 235 & LKBB-060705-019F & 12.7 & 0.148 & 81.6 & LKBB-060705-019W & 98.3 & 0.11 & 75.9 \\
\hline LKBB & SPBA & 212 & LKBB-060705-020F & 13.0 & 0.096 & 79.3 & LKBB-060705-020W & 82.6 & 0.062 & 73.8 \\
\hline LKBB & SPBA & 173 & LKBB-060705-026F & 6.1 & 0.092 & 82.4 & LKBB-060705-026W & 44.8 & 0.064 & 77.1 \\
\hline
\end{tabular}


Table 2. Total mercury concentrations in fillet and whole-body samples of largemouth bass (Micropterus salmoides) and spotted bass (M. punctulatus) collected from Whiskeytown Lake, California, June 7-9, 2005. —Continued

[LKBB, Brandy/Boulder Creek area; LKCC, Clear Creek arm; LKWC, Whiskey Creek arm; LMBA, largemouth bass; SPBA, spotted bass; HgT, total mercury; g, gram; $\mu \mathrm{g}$; microgram; mm, millimeter; wt., weight]

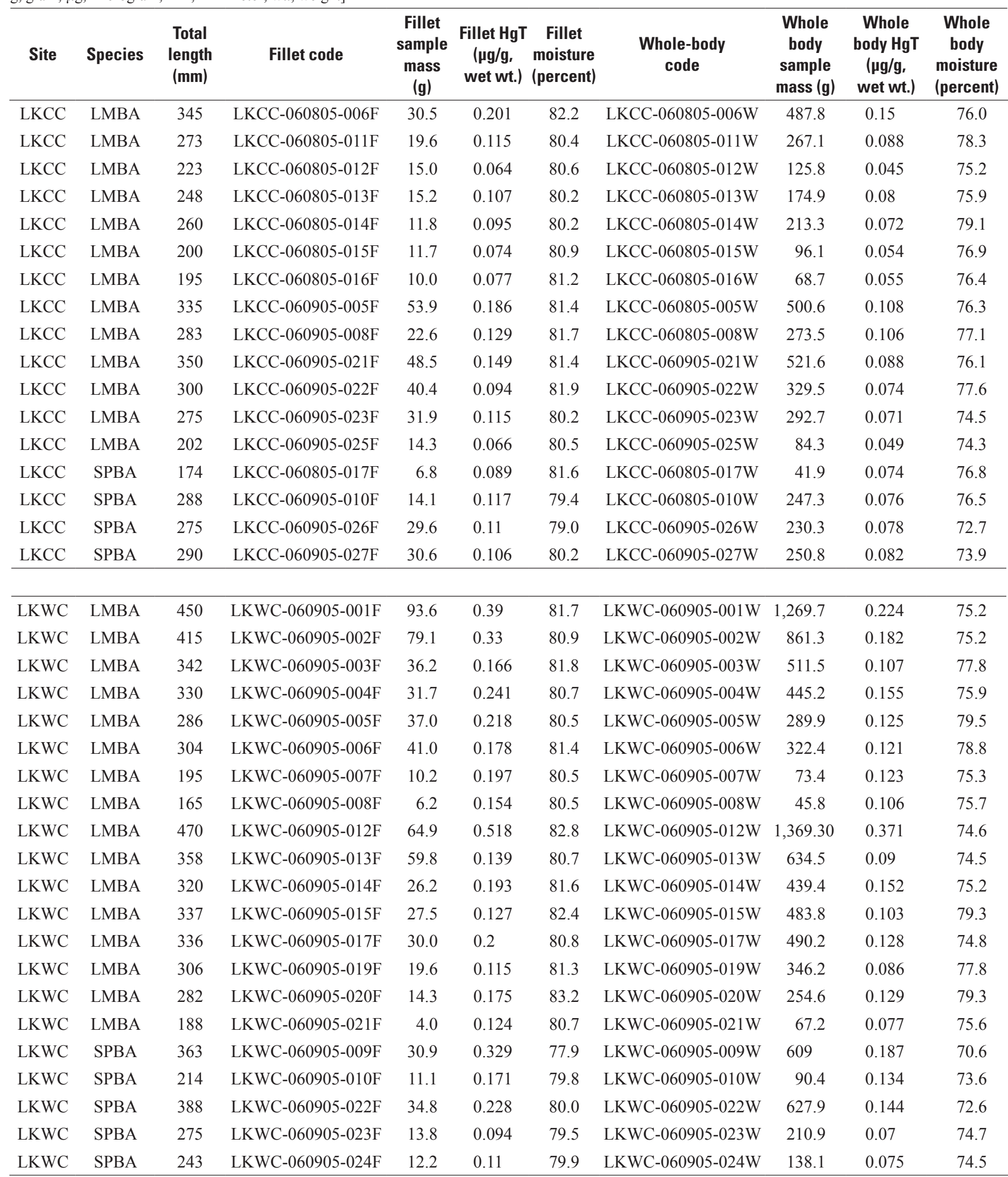




\section{Purpose and Scope}

The purpose of this report is to present information regarding the concentration of metals in sport fish from the Whiskeytown Lake. Data were collected by USGS personnel. In addition, this data report adds to the limited number of studies for metal concentration in sport fish for this lake. The data from this report will be of use to scientists, managers, and other persons concerned with the metals concentrations in sport fish from Whiskeytown Lake and regional sport fisheries.

\section{Field Methods and Sample Preservation Techniques}

Field and laboratory preparatory methods were similar to those used by May and others $(2000,2005)$. All fish were collected by using electrofishing equipment and dip nets. Fish were held in clean containers with ambient water until they were weighed, to the nearest gram, and measured for standard and total length, in millimeters. After recording the length and mass, spines or scales were removed from each fish for future age determination. Each fish was then wrapped in clean, heavy-duty aluminum foil, labeled, placed in a plastic bag on wet ice and held for less than 8 hours. The fish were then taken to the USGS Dixon Field Station laboratory, where they were stored frozen until they were processed and sent to the contract laboratory for chemical analyses.

The processing of fish followed standard procedures (U.S. Environmental Protection Agency, 1995). Fish were handled with powder-free latex gloves, and dissections were performed on a new sheet of heavy-duty aluminum foil for each fish. High-quality stainless steel instruments and disposable scalpel blades were used in the processing of the fish samples. Scalpel blades were changed and instruments were cleaned thoroughly between samples. Cleaning the instruments involved washing with deionized water and laboratory detergent, acid washing, and finally rinsing with deionized water before and after dissection of each fish specimen.

Larger fish were thawed and scaled before dissection. Boneless and skinless fillet portions were taken from the left upper medial-axial region of the fish in an approximately rectangular shape. Excised tissues were placed directly into labeled, chemically cleaned borosilicate-glass jars on a pretared balance. The sample mass was recorded, and a Teflonlined lid was screwed atop each jar and sealed with Parafilm.
Fish tissue samples were stored frozen in sealed sample jars until they were packed in coolers with dry ice and shipped to the contract analytical laboratory at Texas A\&M University in College Station, Texas. The remaining whole-body of each fish was packaged into jars with Teflon-lined lids and analyzed for total metals.

\section{Laboratory Methods of Chemical Analysis}

Analysis of mercury $(\mathrm{Hg})$ in fish samples was done at the Trace Element Research Laboratory (TERL) at Texas A\&M University in College Station, Texas, under the direction of Dr. Robert Taylor. Samples were received frozen and were assigned unique identification numbers upon arrival at the laboratory. Tissue samples were transferred to labeled, tared polyethylene zip-lock bags, weighed, and lyophilized in a Labconco Freezone 12L freeze dryer. Moisture content was determined by weight loss following freeze drying for both fillet and whole-body samples.

Procedures that require tissue samples to be freeze-dried to determine mercury concentrations result in removal of the original moisture in the sample. Additionally, tissue moisture is a relative measure of the quality of the tissue sample. Moisture content was determined by weight loss upon freeze drying and is expressed as weight percentage of the original wet sample. Depending on sample size, either the whole sample or a representative aliquot was frozen and then dried under vacuum until a constant weight was attained. Samples were prepared and dried using plastic materials to minimize potential contamination artifacts.

Both fillet and whole-body tissue samples were prepared for analysis by powdering freeze dried tissue in a Spex 6800 cryomill. Samples were transferred to polycarbonate containers, chilled to liquid nitrogen temperatures, and ground to a fine powder with a stainless steel impacter in the cryomill. Homogenized samples were stored in zip-lock bags until analyzed. Aliquots of dry, powdered tissue samples were weighed to the nearest $0.0001 \mathrm{~g}$ and transferred to polypropylene digestion vessels. Samples were digested at a temperature of $95^{\circ} \mathrm{C}$ with nitric and hydrochloric acids and hydrogen peroxide (3, 1 , and $2 \mathrm{~mL}$ milliliters, respectively) in a CPI graphite block digester. Digest solutions were made to volume with Milli-Q $18 \mathrm{MOhm}$ (megaohm) deionized water and were stored in polyethylene bottles until analyzed. 
Three methods were used to determine metal concentrations in fish tissue: cold-vapor atomic absorption spectroscopy (CVAAS) for HgT in filets and whole body; inductively coupled plasma-mass spectroscopy (ICPMS); and, inductively coupled plasma-optical emission spectroscopy (ICP-OES) for other trace metals in the whole body.

Before samples were analyzed for $\mathrm{Hg}$ by CVAAS, the $\mathrm{Hg}$ was converted to the divalent mercury $\left(\mathrm{Hg}^{2+}\right)$ form. Mercury was digested using a modified version of U.S. Environmental Protection Agency (USEPA) methods 245.5 and 245.6 (U.S. Environmental Protection Agency, 1991, 1995, 2001, 2003). Tissue samples were homogenized in the original sample containers by using a Tekmar Tissumizer, and then subsampled. Tissue subsamples were digested with nitric acid, sulfuric acid, potassium permanganate, and potassium persulfate in polypropylene tubes in a water bath at 90 to 95 degrees Celsius $\left({ }^{\circ} \mathrm{C}\right)$. Before analysis, hydroxylamine hydrochloride was added to reduce excess permanganate, and the samples were brought to volume using distilled-deionized water.

In the CVAAS procedure for determination of $\mathrm{Hg}$, divalent mercury $\left(\mathrm{Hg}^{2+}\right)$ in aqueous samples (digests of tissue samples) is reduced to the elemental state $\left(\mathrm{Hg}^{0}\right)$ by a strong reducing agent (stannous chloride). Gaseous $\mathrm{Hg}^{0}$ enters the sweep gas and is introduced into an atomic absorption cell, where light produced by a mercury-vapor lamp is absorbed by the free $\mathrm{Hg}^{0}$ atoms. Mercury concentration in the sample is determined by comparing light absorption of the sample with that of external calibration standards. The range limit of detection (LOD) for these analyses was 0.01 to $0.06 \mu \mathrm{g} / \mathrm{g}$, dry weight $(\mathrm{dw})$.

Inductively coupled plasma-mass spectroscopy was used during the metals scan to determine arsenic (As), cadmium $(\mathrm{Cd})$, lead $(\mathrm{Pb})$, and selenium $(\mathrm{Se})$. Tissue digests were diluted with Milli-Q $18 \mathrm{MOhm}$ deionized water as necessary to reduce their nitric acid concentrations to no greater than 2 percent $\mathrm{v} / \mathrm{v}$ (volume by volume ) and were then analyzed in pulse mode on a Perkin Elmer/Sciex DRC 2 ICP-MS instrument equipped with a dynamic reaction cell to eliminate molecular ion interferences on several elements (For example: As, Se, $\mathrm{Cr}$, and $\mathrm{V}$ ). Elemental concentrations were determined using internal standards to compensate for slight matrix effects and instrumental performance changes.

Inductively coupled plasma-optical emission spectroscopy was used to determine aluminum (Al), barium (Ba), calcium $(\mathrm{Ca})$, chromium $(\mathrm{Cr})$, copper $(\mathrm{Cu})$, iron $(\mathrm{Fe})$, potassium $(\mathrm{K})$, magnesium $(\mathrm{Mg})$, manganese $(\mathrm{Mn})$, sodium $(\mathrm{Na})$, nickel (Ni), phosphorus (P), sulfur (S), strontium (Sr), titanium (Ti), and zinc $(\mathrm{Zn})$ in fish samples. Digest solutions were analyzed undiluted on an axial Spectro CirOs instrument, using internal standards to compensate for matrix effects and instrument drift. Final calculations utilized off-peak background correction and inter-element correction equations.

\section{Quality Assurance and Quality Control}

As part of normal quality-assurance (QA) and qualitycontrol (QC) procedures, a standard number of procedural blanks, laboratory duplicate samples, spiked samples, and standard reference materials were analyzed at the TERL during 2005-2006 for each set of fish samples from Whiskeytown Lake.

Procedural blanks were analyzed to quantify the amount of total mercury and other metals that may have been added inadvertently during sample processing. A total of 4 procedural blanks were analyzed. All QA/QC results were within acceptable limits for TERL standards for all the samples.

Laboratory replicate samples were analyzed to provide a measure of the precision of the methods used for analysis. Fifteen of the 63 samples were used as laboratory replicates. After the sample was homogenized, two separate subsamples were taken and analyzed. Replicates had to meet certain criteria to fall within the 95 percent confidence interval. If the sample concentration was within 2 to 10 times the limit of detection (LOD), the replicate had to be within 20 percent of the original value. If the sample concentration was greater than 10 times the LOD, the replicate sample had to be within 10 percent of the original value. 
Relative percentage difference (RPD) is another measure of precision for replicate samples. It is computed as 100 times the absolute value of the difference between two replicate analyses divided by their mean. Values of RPD ranged from 0.24 to 9.17 percent, well within acceptable limits are set by TERL.

Spiked samples were analyzed to provide a measure of the accuracy of the methods used for analysis. Subsamples from 18 of the 63 fish were used as spiked samples and were evaluated for spike recovery. After the sample was homogenized, two separate subsamples were taken, one was processed as a sample, and the other spiked with a known quantity of analyte. Spike recovery was calculated as the measured concentration from the spiked sample minus the measured concentration from the unspiked sample, divided by the expected concentration in the spiked sample, and multiplied by 100 percent. Spike recoveries were determined to be between 93.5 to 107 percent. Spike recoveries were considered acceptable if the average recovery was 85 to 115 percent (Robert Taylor, Trace Element Researach Laboratory, College Station, Texas, written commun., 2011).

Standard reference material (SRM) was analyzed to provide an estimate of range in accuracy of the laboratory instrument used for the determination of total mercury concentration and to ensure that this method produced results that were comparable to those obtained by an independent organization. The SRM used by the TERL was dogfish (Squalus sp.) muscle (DORM-2), certified by the National Research Council Canada (NRCC) as having a certified reference value (CRV) of $4.64 \mu \mathrm{g} / \mathrm{g}$ mercury (dry). The percentage recovery for the 18 analyses of DORM-2 in the three sample sets ranged from 82.7 to 107 percent, which is within acceptable limits (Robert Taylor, Trace Element Research Laboratory, College Station, Texas, written commun., 2011).

\section{Results and Discussion}

A total of 63 black bass (largemouth and spotted bass) were collected and processed for total mercury in fillet and whole-body samples (table 2). Whole-body samples were also analyzed for total metals (table 3). Total mercury in fillet samples ranged from 0.06 to $0.52 \mu \mathrm{g} / \mathrm{g}$ ww (wet weight) and 0.04 to $0.37 \mu \mathrm{g} / \mathrm{g}$ ww in whole-body samples. Mercury concentrations in 5 of the 30 black bass fillet samples that were of legal catch size ( $\geq 305$ millimeters in length) exceeded the USEPA water-quality criterion for the protection of human health $(0.3 \mu \mathrm{g} / \mathrm{g} \mathrm{ww})$, (U.S. Environmental Protection Agency, 2001). Black bass collected from Whiskeytown Lake show a general trend of increasing mercury concentration with increasing size (figure 2) and similar concentrations of total mercury in fillet and whole-body samples $\left(\mathrm{r}^{2}=0.937\right)$ (figure 3).

Each whole-body sample was processed for total metals scan. The following metals of ecological importance are reported alphabetically in $\mu \mathrm{g} / \mathrm{g}$ dry weight with mean $\mu \mathrm{g} / \mathrm{g}$, range $\mu \mathrm{g} / \mathrm{g}$, and percent of non-detects (percent nd) in parentheses: arsenic $(1.1 \mu \mathrm{g} / \mathrm{g}, 1.82-0.746 \mu \mathrm{g} / \mathrm{g})$, cadmium $(1.11 \mu \mathrm{g} / \mathrm{g}, 1.35-0.024 \mu \mathrm{g} / \mathrm{g}, 2$ percent nd $)$, copper $(2.18 \mu \mathrm{g} / \mathrm{g}$ , 9.54-0.89 $\mu \mathrm{g} / \mathrm{g})$, mercury $(0.466 \mu \mathrm{g} / \mathrm{g}, 1.46-0.18 \mu \mathrm{g} / \mathrm{g})$, nickel $(5.83 \mu \mathrm{g} / \mathrm{g}, 172.0-0.46 \mu \mathrm{g} / \mathrm{g}, 24$ percent nd), lead $(0.088 \mu \mathrm{g} / \mathrm{g}, 0.205-0.047 \mu \mathrm{g} / \mathrm{g}, 90$ percent nd), selenium $(2.4 \mu \mathrm{g} / \mathrm{g}, 3.83-1.8 \mu \mathrm{g} / \mathrm{g})$, and zinc $(75.39 \mu \mathrm{g} / \mathrm{g}, 121.0$ $48.4 \mu \mathrm{g} / \mathrm{g}$ ). Visual comparisons of the ranges of data from metal scans indicated that there is no substantial difference between collection area or species for any metal. 


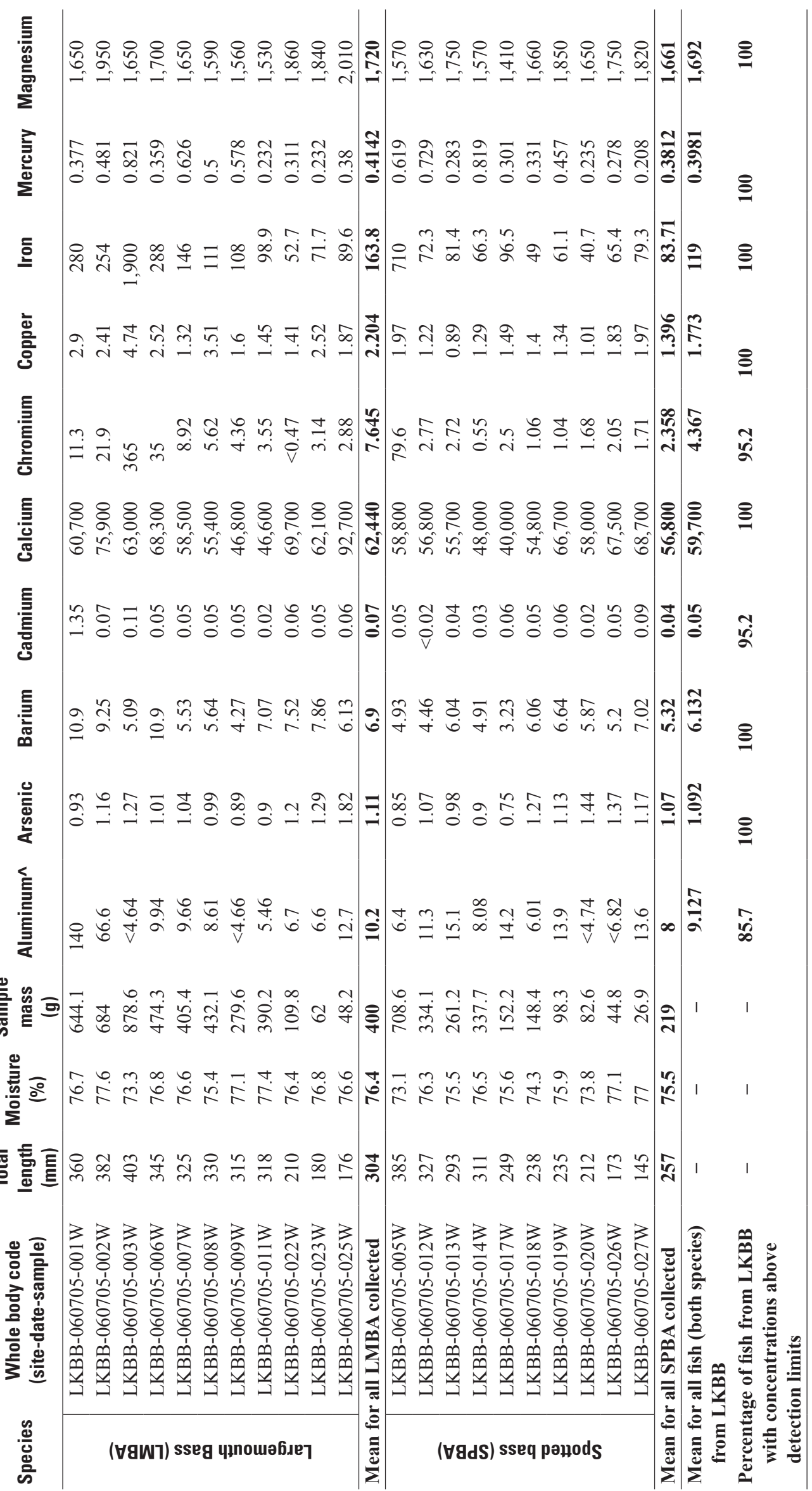


恶|율

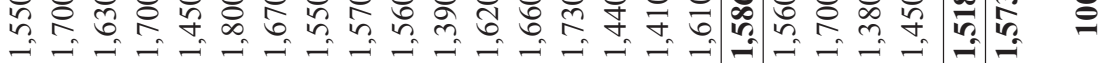

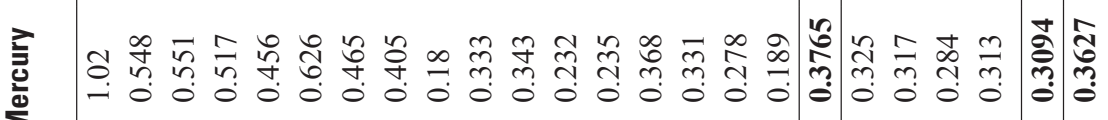

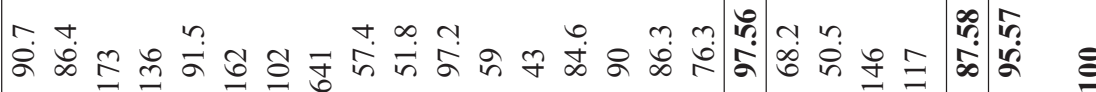

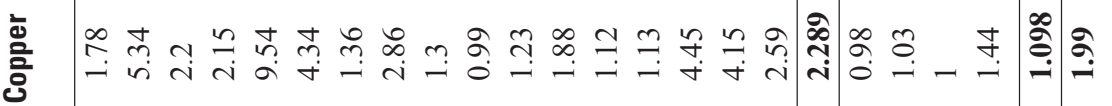

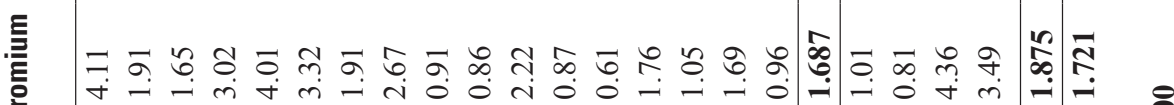

声 \& \& \& \& \& \& \& \& \& \& \& \& \& \& \&

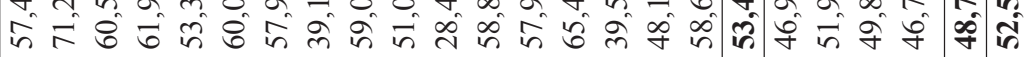

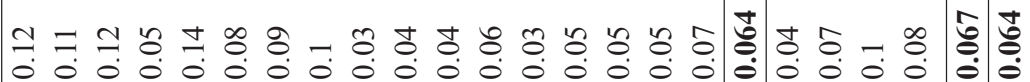

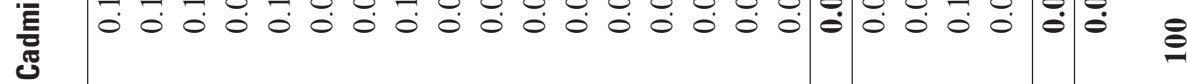

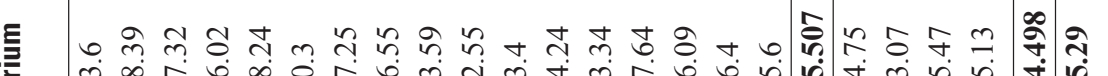

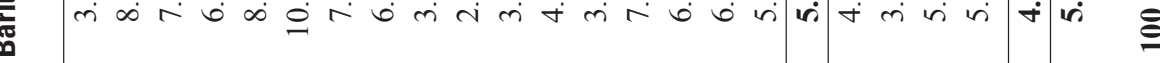

.

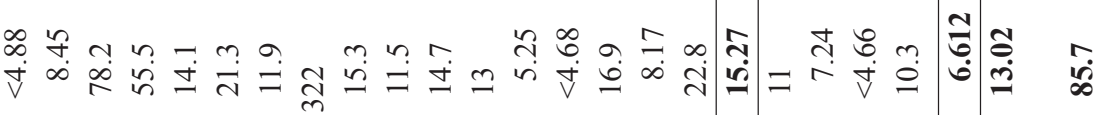

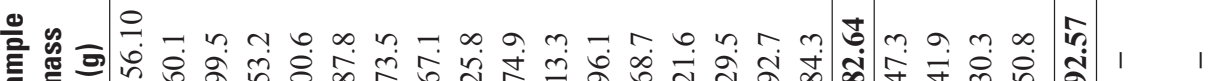

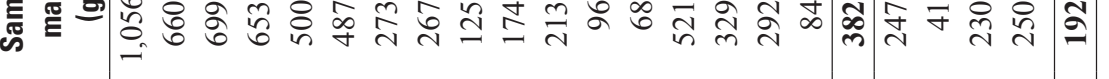

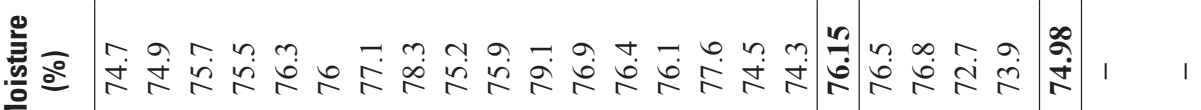

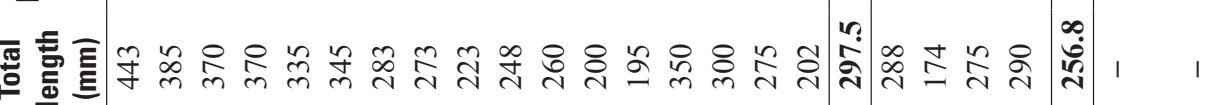

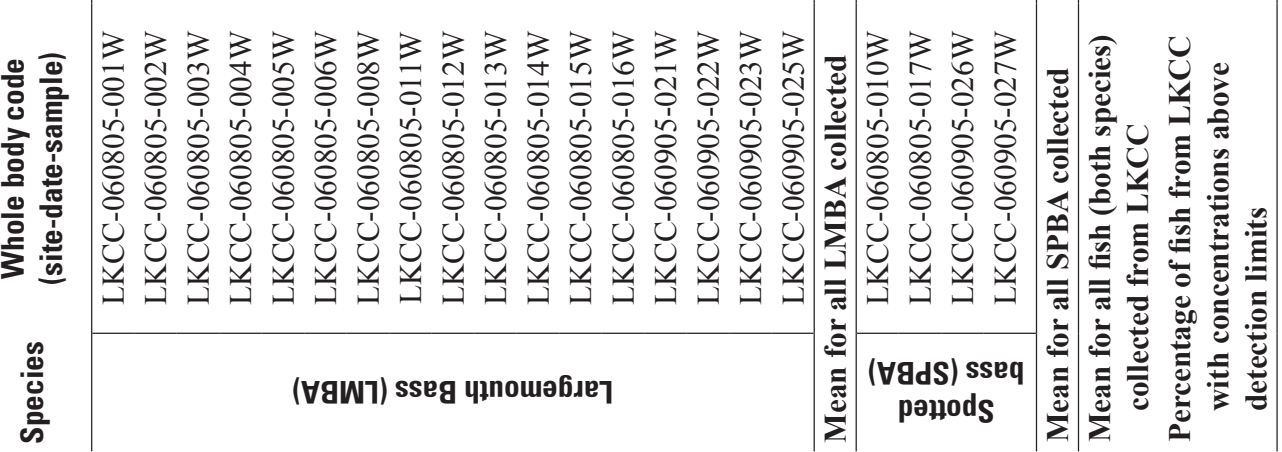




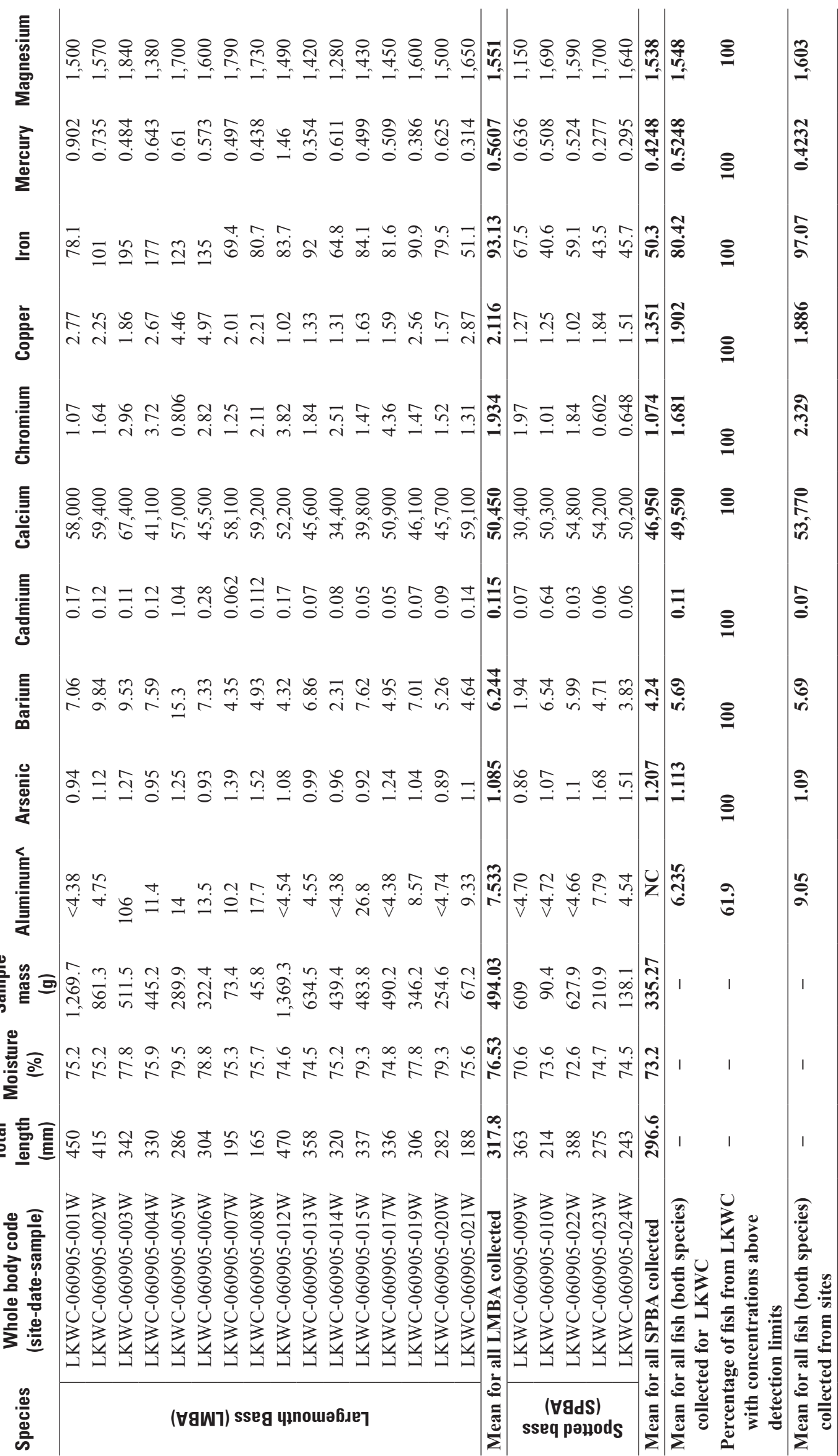


芩 这蛋号 部

焉

洁递

बै

遅

过

西

政

.

蕋

일

节

空

is

跑

気完

范

苛罗

言

훙 ही

。ํํㅇ

원

空造

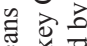

语

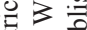

造

过

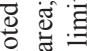

政

U⿺辶寸

咅

원

3 .

क्ष

政

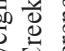

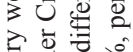

की $\overline{0}$ oิ

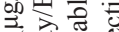

表 댔

की क्षे फे

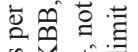

宩:

论

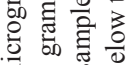

药

$\Xi \ddot{\partial} \doteq$

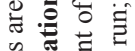

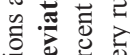

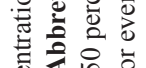

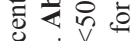

言它

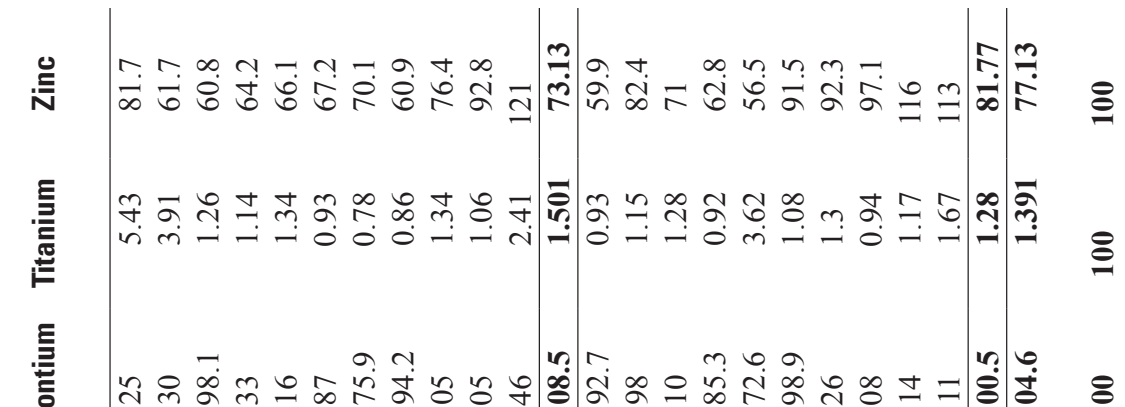

Ұ

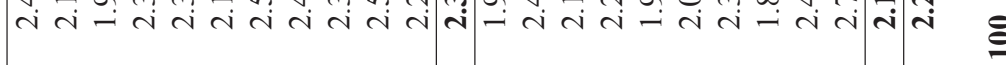

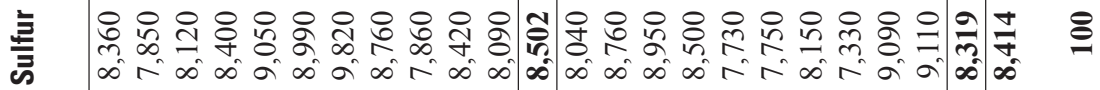

重

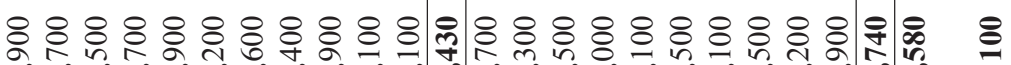

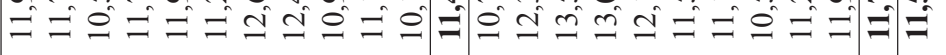

\& \& \& \& \& \& \& \& \& \& \&융영 \& \& \& \& \& \& \& \& \&

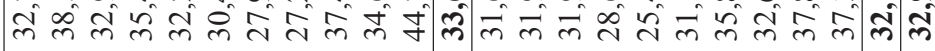

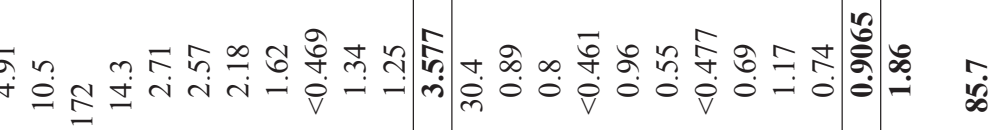

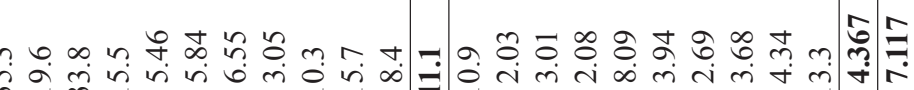

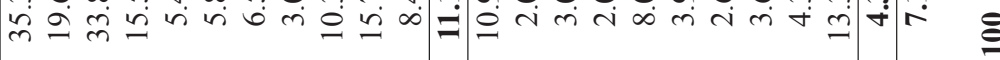

言高总

产

嵒言言互

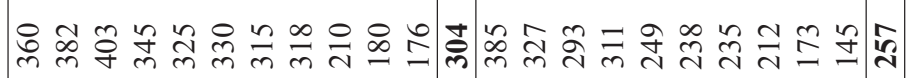

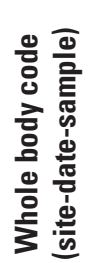

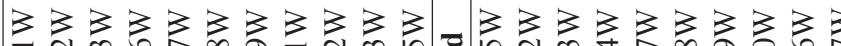

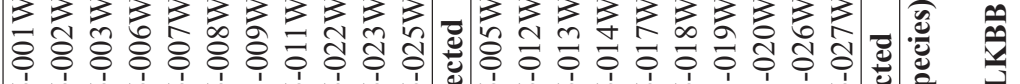

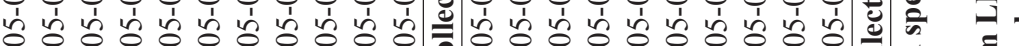

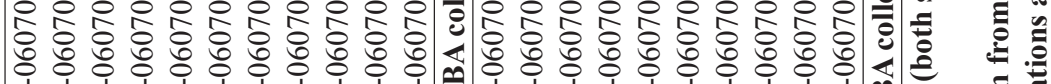

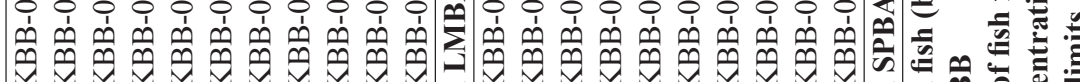

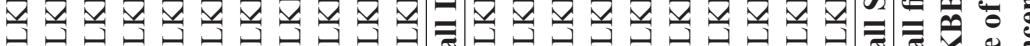

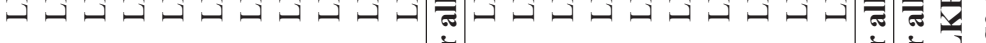

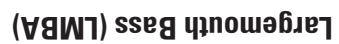

בֶּ

( $\forall$ gdS) sseq penods

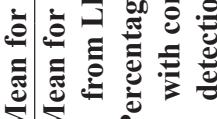




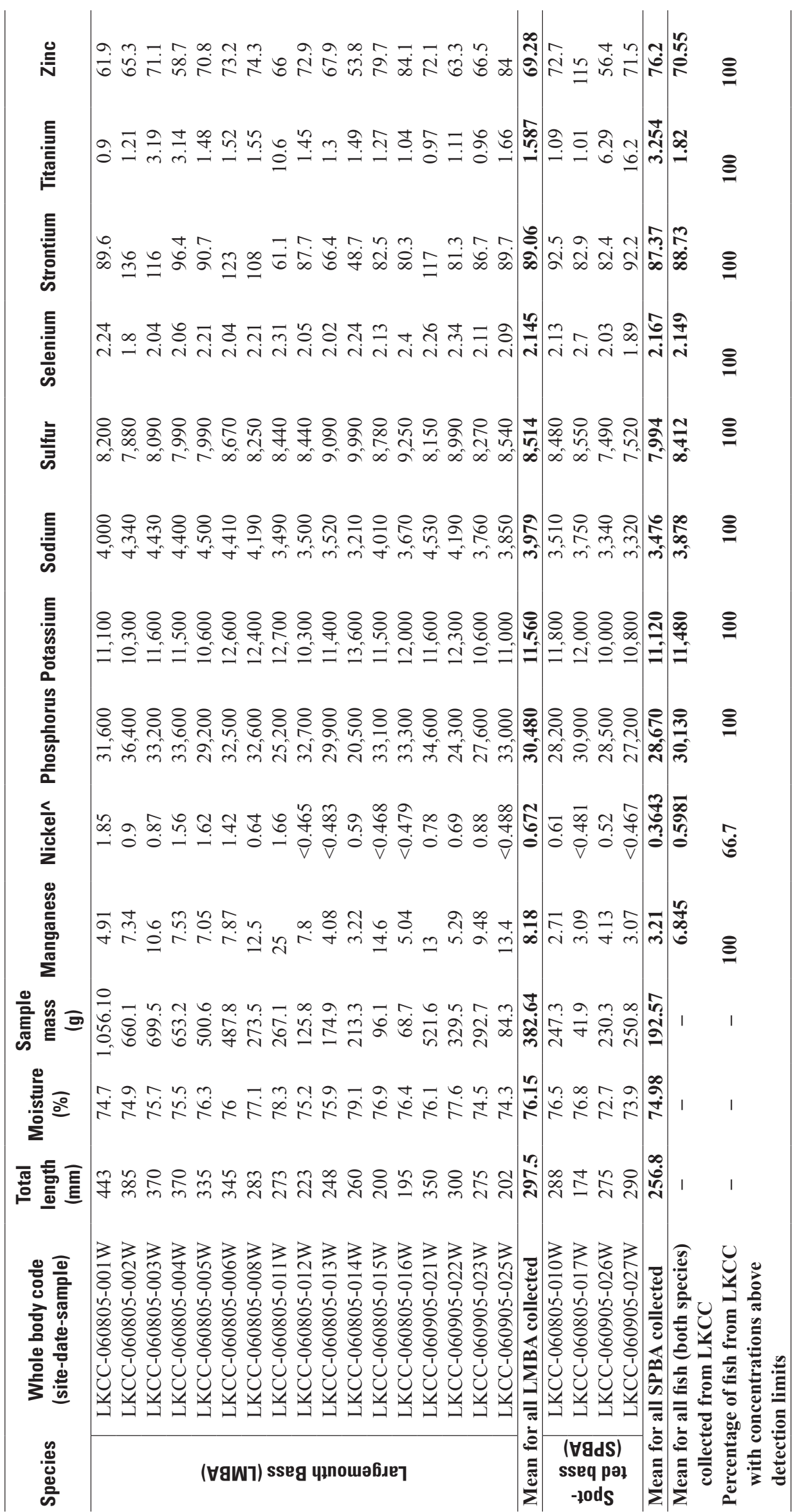


氜

.

过

.

政

$=$

要

घี

乙。

要

बึ

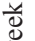

政

o

ส

广

西

$y$

政

$\overline{0}$

存 당

क्षे के

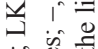

㤟

$\ddot{*} \mathrm{~V}$

年

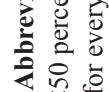

记芯馬

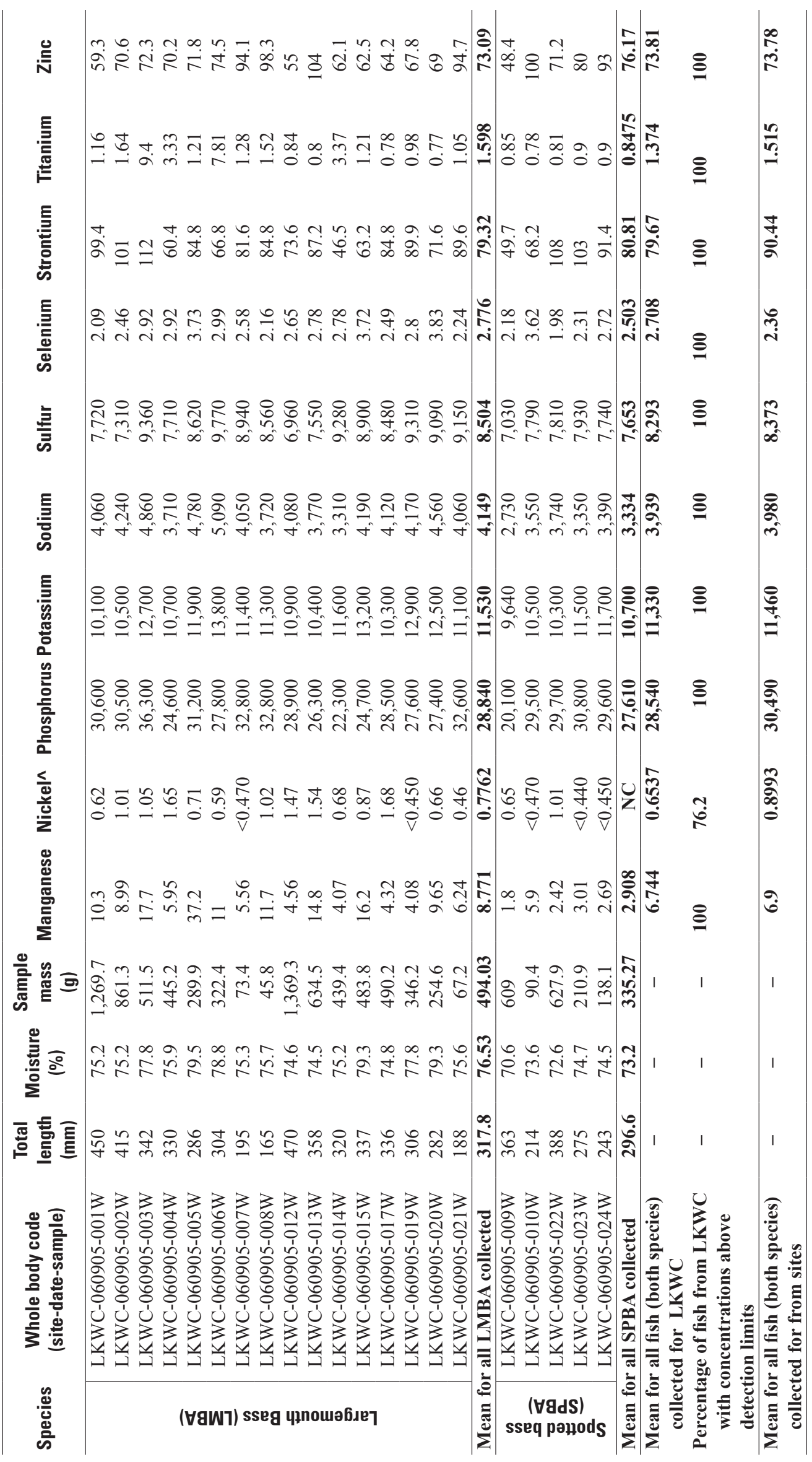




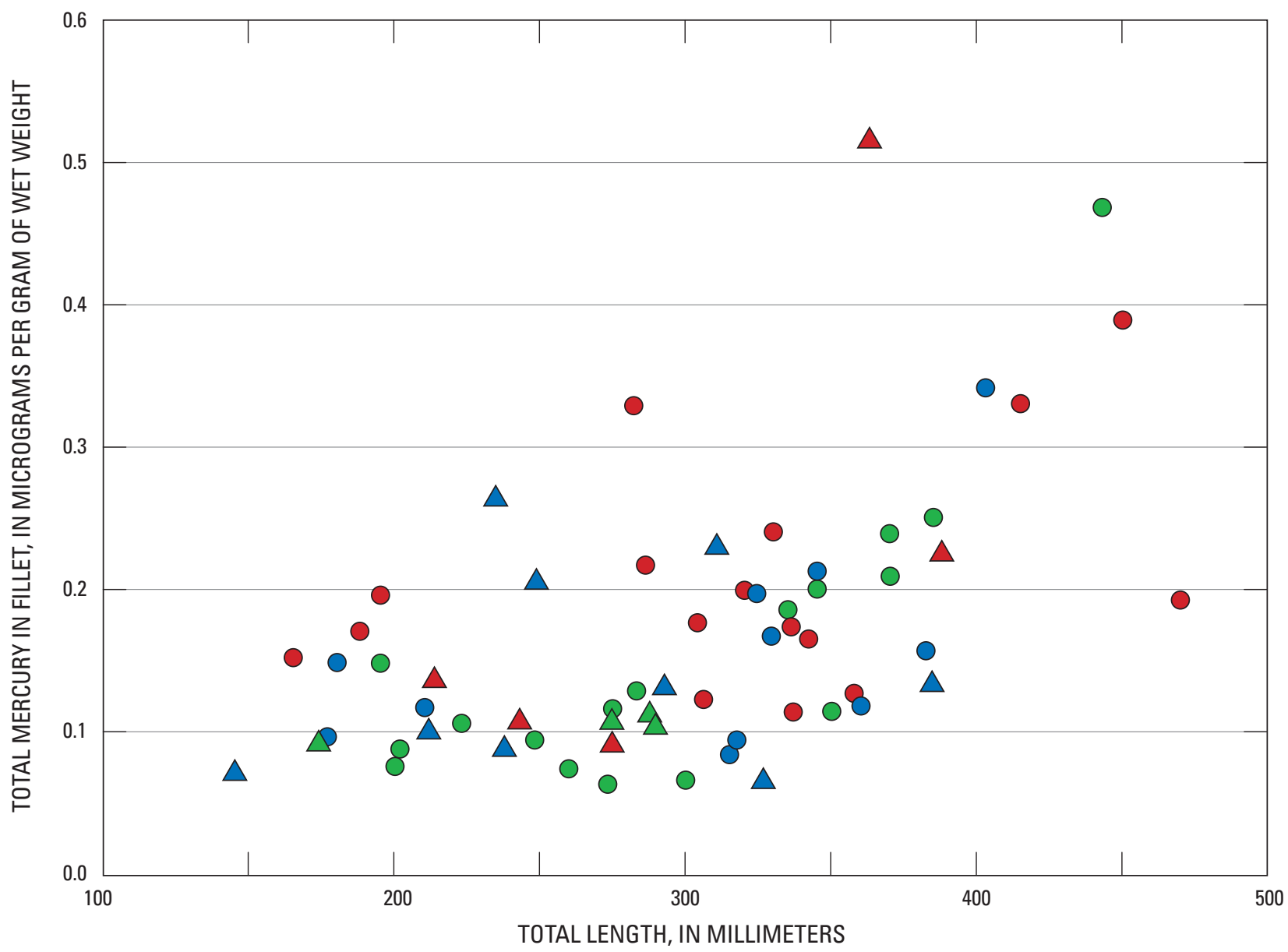

EXPLANATION

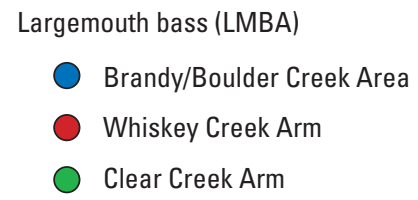

Spotted bass (SPBA)

$\triangle$ Brandy/Boulder Creek Area
$\triangle$ Whiskey Creek Arm
$\Delta$ Clear Creek Arm

Figure 2. Mercury concentration for all bass (Micropterus spp.) samples collected from Whiskeytown Lake, California, 2005 in relation to total length.

The data presented in this report represent a baseline for future monitoring efforts. Black bass in Whiskeytown Lake have elevated concentrations of total mercury and show a bioaccumulation effect of increasing mercury with increasing size. While mercury values from fish collected from Whiskeytown Lake are not as elevated as values from fish in the adjacent Trinity Lake and watershed (May and others 2005), it is evident that more samples are needed to thoroughly evaluate the potential risk these fish may pose to human and wildlife consumers. 


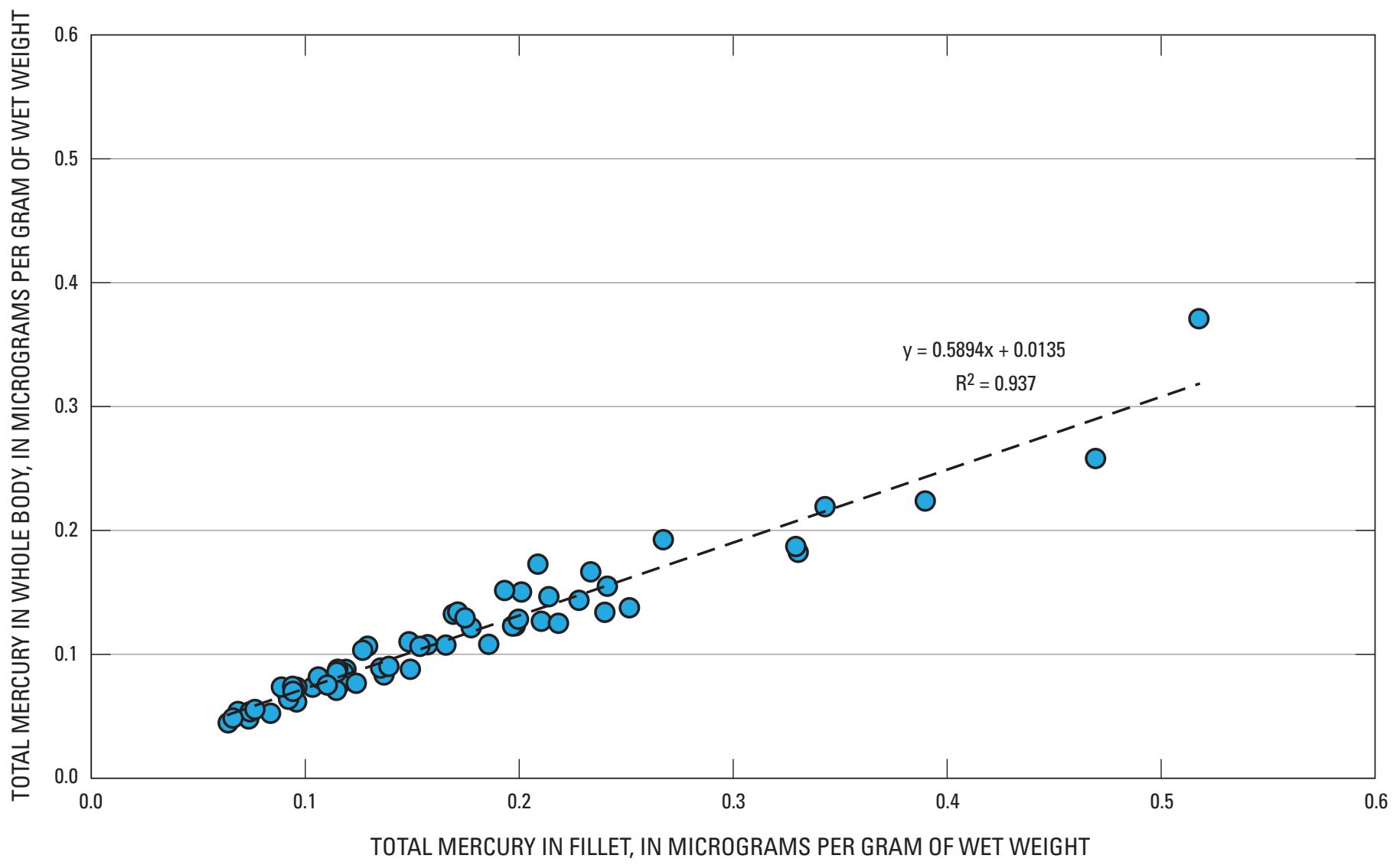

Figure 3. Correlation plot of mercury concentration in fillet samples in relation to whole-body samples for for all bass (Micropterus spp.) samples collected from Whiskeytown Lake, California, 2005.

\section{Acknowledgements}

Funding for this study was provided by the USGS-NPS Water Quality Cooperative Program, and the U.S. Department of Interior Burned Area Rehabilitation Program. We thank Jennifer Gibson, Russ Weatherbee, and Brian Rasmussen of the Whiskeytown National Recreation Area, who helped with procuring funding for these analyses and assisted with logistics associated with the collection. Skylar Feltman of USGS Biological Resources Discipline helped with processing fish samples.

\section{References}

Alpers, C.N., Hunerlach, M.P., May, J.T., and Hothem, R.L., 2005, Mercury contamination from historic gold mining in California: U.S. Geological Survey Fact Sheet 2005-3014, $2^{\text {nd }}$ ed., 6 p. Available at http://pubs.usgs.gov/fs/2005/3014/ fs2005_3014_v1.1.pdf
California Department of Conservation, 2000, California's Abandoned mine lands: Chapter 3.3 Clear Creek Watershed, p. 41-47,Volume II: A report on the magnitude and Scope of the issue in the State: California Department of Conservation, Abandoned Mines Unit, Sacramento, California, 137 p.

May, J.T., Hothem, R.L., Alpers, C.N., and Law, M.A., 2000, Mercury bioaccumulation in fish in a region affected by historic gold mining: The South Yuba River, Deer Creek, and Bear River Watersheds, California, 1999: U.S. Geological Survey, Open-File Report 00-367, 35 p. Available at http://pubs.usgs.gov/of/2000/0367/report.pdf

May, J.T., Hothem, R.L, and Alpers, C.N., 2005, Mercury Concentrations in fishes from select water bodies in Trinity County, California, 2000-2002: U.S. Geological Survey Open-File Report 2005-1321, 14 p. Available at http://pubs.usgs.gov/of/2005/1321/USGS_2005-1321.pdf

Moore, J.N., and Hughes, D., 2003, Trace metals in sediments of a mine impacted river basin: Clear Creek, California Project, Final Report: Department of Geology, University of Montana, Missoula, masters thesis, December 30, 2003, $136 \mathrm{p}$. 
National Park Service, 1999, General Management Plan and Environmental Impact Statement Whiskeytown Unit Shasta County, California, 117 p., accessed June, 2008 at http:// www.nps.gov/whis/parkmgmt/upload/GMPfinal.pdf

U.S. Environmental Protection Agency, 1991, Methods for the determination of metals in environmental samples: U.S. Environmental Protection Agency, Office of Research and Development, Environmental Monitoring Systems Laboratory, EPA- PA/600 4-91-010, 293 p.

U.S. Environmental Protection Agency, 1995, Guidance for assessing chemical contaminant data for use in fish advisories, Volume 1, Fish sampling and analysis (2nd ed.): U.S. Environmental Protection Agency, Office of Water, EPA823-R-95-007, variously paged.
U.S. Environmental Protection Agency, 2001, Water quality criterion for protection of human health-Methylmercury: U.S. Environmental Protection Agency, Office of Water, EPA-823-R-01-001, 269 p.

U.S. Environmental Protection Agency, 2003, Draft update IVA of SW-846, 7000 series, Method 7473, Mercury in solids and solutions by thermal decomposition, amalgamation, and atomic absorption spectrophotometry: U.S. Environmental Protection Agency, Office of Water, accessed July, 2005 at http://www.epa.gov/epaoswer/hazwaste/test/up4a.htm\#7 series 
$\stackrel{\circ}{?}$

3

产

言

옿

3

$\frac{\omega}{\omega}$

음

꿈

ग

윽

동 ำㅇำ

ํㅐㅇำ

혼

5 